\title{
Assessment of Advanced Lines of Cowpea for Nodulation, Dry Matter Accumulation And Grain Yield
}

\author{
U. N. Emiri \\ Department of Agricultural Education, Isaac Jasper Boro College of Education, Bayelsa State, Nigeria
}

\begin{abstract}
In an experiment conducted at University of Agriculture, Abeokuta Teaching and Reaserch farm (Alabata), twenty one cultivars of cowpea Vignaungiuculata $(L)$ Walp were evaluated for their nodulation, dry matter accumulation and grain yield.The varieties were laid out in a randomized complete block design and replicated three times.Two categories of varieties were observed in the study. The first category consist of Danila, IT 96D -651, IT96K-113-6, IT97K-508-2, IT96D-648 which produced high nodule count (50-81 per plant) and biomass $(0.777$ t/ha to $1.733 t /$ ha) thus having potential in a crop/livestock system for fodder production.The second category of varieties IT95K-366-1, IT93K-452-1, IT95K-1090-12, IT97K-1034-14, IT97K-508-2, IT95K-1091-3, IT86D-719,Ife brown produced high biomass (1.040t/ha to 1.733t/ha) and good grain yield $(1257 \mathrm{~kg} / \mathrm{ha}$ to $2991 \mathrm{~kg} / \mathrm{ha}$ ). This group can therefore be cultivated as dual purpose varieties.Other agronomic traits of the varieties were synchronous maturity date of 65DAP and 77DAP giving the producer and advantageof harvesting in one or two harvesting operations.
\end{abstract}

Keywords: Nodulation, Dry Matter, DAP, Yield, Biomass

\section{Introduction}

Cowpea (Vignaunguiculata $(\mathrm{L})$ Walp) belongs to the family Fabacene.Cultigroupunguiculatais the most diverse of the cultivated subspecies. It is the most important grain legume crop throughout the tropical belt of Africa and America. Cowpea is a key staple food for the poor in the tropical and sub-tropical Africa because of the protein that it provides for the urban and rural population. It is relatively cheap and readily available to the poor. (Aghali, 1991) The chemical composition of cowpea compares well with that of most edible legumes with composition as follows; $25-30 \%$ protein, $7 \%$ crude fibre, $49 \%$ Ash (Singh, 1993). Cowpea protein contains relatively high lysine content of (55-60\%) thus making cowpea an excellent protein supplement to cereal based diet. In Nigeria, cowpea is boiled and eaten in form of dry seeds, green pods, green seed and tender green leaves, as well as fried bean cake and moin-moin. It can be used for baking by adding wheat flour to it. Green beans or cut green pods used as vegetable is of secondary importance for making soup. Cowpea has the ability to fix atmospheric nitrogen efficiently up to $240 \mathrm{~kg}$ nitrogen per hectare it thus provides a high proportion of its own nitrogen requirements besides leaving a fixed nitrogen deposit in the soil of up to $60-70 \mathrm{~kg}$ per hectare for succeeding crop (Miller et al., 1986)

Cowpea plays a vital role for soil fertility restoration, which results from its nitrogen fixing root nodules. Nitrogen fixation is achieved through the symbiotic association between the rhizobia bacteria and the root legume. This infects the root of cowpea plant, forming nodules. These rhizobia reduce atmospheric nitrogen $\left(N_{2}\right)$ into compounds assimilable by the host plant. Nitrogenous substances accumulate in the leaves during vegetative growth and they are then transported to the seed during grain filling and subsequently resulting in good grain yield. Cowpea fits very well as a rotation/alternate crop during the dry season, as it requires a moderate amount of water and matures within $60-80$ days of planting. Despite the popularity of cowpea as a food item, production is not popular among farmers in the humid tropics. Most of the cowpea consumed in the humid south-western Nigeria is produced from the drier savannah of the north.Production of the crop is not very popular among the farmers in the humid southwest because of insect pest particularly Maruca and disease problems which cause low yield (Singh, 1993). The crop is susceptible to insect pest at virtually all stages of development. Such pests include Leaf thrips, aphids, maruca, and bruchids. Several cowpea varieties have been developed at International Institute of Tropical Agriculture (IITA), which combines resistance to viruses, thrips, nematodes, aphids, bruchids and striga with high yield. (Singh et al, 1997) Cowpea improvement involves developing progeny lines through many generations up to $\mathrm{F}_{6}$. By the $5^{\text {th }}$ generation of crossing, the resulting lines are regarded as advanced lines. Such lines need to be evaluated in different agroecologies while promising lines are advanced to multi-locational yield trials before their eventual release.

\section{Objectives Of The Study}

The objectives of this study were:

1. To assess the contribution of nodulation to grain yield and dry matter production.

2. To determine the varieties that have potentials for high biomass and grain yield.

3. To recommend the high yielding varieties to farmers. 
Study Area

\section{Materials And Methods}

The experiment was conducted on the teaching and research farm of University of Agriculture, Alabata, Abeokuta, Nigeria (Latitude $7^{\circ} 20^{\prime} \mathrm{N}$ and Longitude $3^{\circ} 23^{\prime} \mathrm{E}$ ) to evaluate 21 lines of cowpea for productivity. A preplanting operation was carried out which involved a general view of the farm sites to identify the weed types, vegetation and topography.

\section{Experimental Design, Treatments And Plot Sizes}

The field was laid out using a 3, 4, 5 Pythagoras procedure. The varieties were evaluated in a randomized complete block design in three replications during the late cropping season. Each plot that consisted of five rows had a gross size of $5 \mathrm{~m} \times 4 \mathrm{~m}$ and each replicate comprised of 21 plots giving a total of 63 plots. The net size of the plot was $3 \mathrm{~m} \times 2 \mathrm{~m}$. The cowpea lines were supplied by International Institute of Tropical Agriculture (IITA).

\section{Cultural Practices}

Two seeds of cowpea were planted in hills spaced at $20 \mathrm{~cm}$ in $1 \mathrm{~m}$ width row. Planting was done by dibbling. Weeds were controlled by hoe at 3 and 6 weeks after planting using West African hoes. Insect pests were controlled by the application of Sherpa plus (formulated mixture cypermethrin + dimethoate) at the rate of $20 \mathrm{~mL} / 10 \mathrm{~L}$ of water. Spraying against insect pests commenced five weeks after planting (WAP) and was repeated at ten days interval until three sprayings were done and when the pods had started maturing.

\section{Data Collection Nodule Count}

This commenced 2 weeks after planting (WAP) and continued weekly until flowering stage (35 DAP). Four plants from two stands were randomly uprooted along the border rows. Roots of the uprooted seedlings were detached and the nodules counted. The nodules counted were enveloped and dried in an oven at $70^{\circ} \mathrm{C}$ for 24 hours. Four samplings were done.

\section{Dry Matter Production}

The shoots of the four randomly uprooted plants used for nodule count were bagged and weighed before and after drying in the oven at $70^{\circ} \mathrm{C}$ for 48 hours. This was done repeatedly at weekly intervals until flowering stage (35 DAP). The shoot sampling commenced 2 weeks after planting (WAP).

\section{Number Of Days To 50 Percent Flowering}

This was taken as the number of days from planting till when 50 percent of the stands on the entire plot had flowered.

\section{Number Of Days To 90 Percent Maturity}

Days to 90 percent maturity was taken as the number of days from planting to the time when 90 percent of the total pods had reached physiological maturity that the pods were fully filled and were already turning brown in colour.

\section{Number Of Peduncles Per Plant}

Four plants harvested from the border row were used for this. The peduncles from these plants were counted and the average per plant calculated.

\section{Pods Per Peduncle}

Pods of each peduncle of the four plants harvested were counted and average of pods per peduncle calculated.

\section{Pods Per Plant}

Number of pods per plant were obtained as an average of pods of four plants from the border row.

Pods Yield

The total pods harvested from the net plot was weighed to obtain the pod yield.

Pod Length

Pod length was obtained per variety. Length of the pods obtained from the four harvested plants from the border rows were measured at harvest.

\section{Grain Filling}

Grain filling was obtained by estimating the difference in number of days to 50 percent flowering and number of days to 90 percent maturity.

\section{Number Of Seeds Per Pod}

Number of seeds per pod was obtained as an average number of seeds of five pods.

\section{One Hundred Seed Weight}

100 seed weight was obtained by counting 100 seeds from each plot yield and weighing using the top loading mettler balance. 


\section{Grain Yield}

The grain yield was obtained by threshing the pods after harvesting, winnowing and weighing of total grains obtained from the net plot.

\section{Cowpea Fodder Yield}

An average of 10 plants were cut at above ground level, dried and weighed to determine the cowpea fodder. This was done after harvesting the grain.

\section{Statistical Analysis}

The data obtained were subjected to analysis of variance (ANOVA) and means separated by standard error of means. Correlation Co-efficient and regression were also done to determine the relationship among characters or parameters.

\section{Number Of Nodules And Dry Weight}

\section{Results}

The result of the number of nodules and dry weight are shown in Table 1.

Significant differences exist among the cultivars for number of nodules at the seedling (14 DAP) and vegetative stages $(21-35$ DAP) of development. However, only the nodule weight of cowpea at 28 DAP differed significantly among the varieties.

The peak nodulation period was at 14 DAP and nodulation declined until 35 DAP for some varieties like IT96D-651, IT97K-608-4, and Ife brown as shown in Table 1.

Table 1: Analysis of Variance on nodule number and dry weight.

\begin{tabular}{|l|l|l|l|l|l|l|l|l|}
\hline VARIETIES & NNP & NNP & NNP & NNP & NDWP & NDWP & NDWP \\
14 DAP & 21 DAP & 28 DAP & 35 DAP & 14 DAP & 21 DAP & 28 DAP & 35 DAP \\
\hline$I T 95 K-366-1$ & $6 \mathrm{kl}$ & $6 \mathrm{fg}$ & $5 \mathrm{~h}$ & $7 \mathrm{efg}$ & 0.010 & 0.040 & $0.037 \mathrm{ghi}$ & 0.033 \\
\hline$I T 93 K-452-1$ & $10 \mathrm{fgh}$ & $14 \mathrm{c}$ & $3 \mathrm{i}$ & $5 \mathrm{gh}$ & 0.017 & 0.050 & $0.010 \mathrm{k}$ & 0.027 \\
\hline$I T 95 K-1090-12$ & $8 \mathrm{ij}$ & $8 \mathrm{e}$ & $7 \mathrm{gh}$ & $6 \mathrm{fg}$ & 0.017 & 0.033 & $0.050 \mathrm{ef}$ & 0.043 \\
\hline$I T 96 D-651$ & $13 \mathrm{~cd}$ & $11 \mathrm{~d}$ & $15 \mathrm{c}$ & $9 \mathrm{~d}$ & 0.023 & 0.040 & $0.037 \mathrm{~b}$ & 0.037 \\
\hline$I T 96 K-113-6$ & $11 \mathrm{fg}$ & $19 \mathrm{~b}$ & $14 \mathrm{~d}$ & $13 \mathrm{~b}$ & 0.017 & 0.037 & $0.050 \mathrm{ef}$ & 0.067 \\
\hline$I T 93 K-686-2$ & $9 \mathrm{ghi}$ & $11 \mathrm{~d}$ & $9 \mathrm{f}$ & $6 \mathrm{efg}$ & 0.017 & 0.027 & $0.040 \mathrm{gh}$ & 0.040 \\
\hline$I T 97 K-608-14$ & $16 \mathrm{ab}$ & $13 \mathrm{c}$ & $5 \mathrm{~h}$ & $3 \mathrm{i}$ & 0.047 & 0.033 & $0.013 \mathrm{k}$ & 0.010 \\
\hline$I T 97 K-837-8$ & $5 \mathrm{~m}$ & $6 \mathrm{efg}$ & $3 \mathrm{i}$ & $2 \mathrm{i}$ & 0.010 & 0.027 & $0.013 \mathrm{k}$ & 0.027 \\
\hline$D A N I L A$ & $16 \mathrm{a}$ & $21 \mathrm{a}$ & $26 \mathrm{a}$ & $18 \mathrm{a}$ & 0.027 & 0.067 & $0.117 \mathrm{a}$ & 0.090 \\
\hline$I T 97 K-1034-14$ & $11 \mathrm{ef}$ & $14 \mathrm{c}$ & $7 \mathrm{fg}$ & $8 \mathrm{de}$ & 0.020 & 0.040 & $0.030 \mathrm{hij}$ & 0.030 \\
\hline$I T 97 K-508-2$ & $13 \mathrm{de}$ & $21 \mathrm{a}$ & $9 \mathrm{f}$ & $13 \mathrm{~b}$ & 0.023 & 0.047 & $0.040 \mathrm{fgh}$ & 0.057 \\
\hline$I T 95 K-1091-3$ & $4 \mathrm{~m}$ & $3 \mathrm{~h}$ & $6 \mathrm{gh}$ & $4 \mathrm{hi}$ & 0.010 & 0.010 & $0.057 \mathrm{de}$ & 0.023 \\
\hline$I T 97 K-499-8$ & $9 \mathrm{ghi}$ & $5 \mathrm{~g}$ & $6 \mathrm{gh}$ & $7 \mathrm{def}$ & 0.017 & 0.017 & $0.027 \mathrm{ij}$ & 0.053 \\
\hline$I T 97 K-899-180$ & $3 \mathrm{~m}$ & $2 \mathrm{~h}$ & $3 \mathrm{i}$ & $3 \mathrm{i}$ & 0.013 & 0.010 & $0.020 \mathrm{jk}$ & 0.020 \\
\hline$I T 94 K-437-1$ & $6 \mathrm{jk}$ & $8 \mathrm{e}$ & $9 \mathrm{f}$ & $6 \mathrm{fg}$ & 0.017 & 0.033 & $0.037 \mathrm{ghi}$ & 0.053 \\
\hline$I T 97 K-403-2$ & $8 \mathrm{i}$ & $7 \mathrm{ef}$ & $6 \mathrm{gh}$ & $4 \mathrm{hi}$ & 0.010 & 0.020 & $0.043 \mathrm{fg}$ & 0.053 \\
\hline$I T 97 K-499-39$ & $4 \mathrm{~m}$ & $7 \mathrm{ef}$ & $2 \mathrm{i}$ & $4 \mathrm{hi}$ & 0.010 & 0.037 & $0.010 \mathrm{k}$ & 0.027 \\
\hline$I T 96 D-648$ & $10 \mathrm{fgh}$ & $17 \mathrm{~b}$ & $11 \mathrm{e}$ & $18 \mathrm{a}$ & 0.023 & 0.060 & $0.047 \mathrm{cfg}$ & 0.087 \\
\hline$I T 97 K-497-2$ & $9 \mathrm{hi}$ & $7 \mathrm{ef}$ & $11 \mathrm{e}$ & $6 \mathrm{fg}$ & 0.020 & 0.023 & $0.083 \mathrm{~b}$ & 0.043 \\
\hline$I T 86 D-719$ & $9 \mathrm{ghi}$ & $11 \mathrm{~d}$ & $12 \mathrm{e}$ & $9 \mathrm{~d}$ & 0.020 & 0.043 & $0.067 \mathrm{~cd}$ & 0.063 \\
\hline$I F E B R O W N$ & $15 \mathrm{bc}$ & $11 \mathrm{~d}$ & $21 \mathrm{~b}$ & $11 \mathrm{c}$ & 0.043 & 0.040 & $0.077 \mathrm{bc}$ & 0.050 \\
\hline$S E \pm$ & $\mathbf{3 . 7 8}$ & $\mathbf{4 . 0 5}$ & $\mathbf{4 . 3 9}$ & $\mathbf{4 . 8 2}$ & $\mathbf{0 . 0 0}$ & $\mathbf{0 . 0 0}$ & $\mathbf{0 . 0 0}$ & $\mathbf{0 . 0 0}$ \\
\hline
\end{tabular}

Nodulation increased significantly between 14 DAP and 21 DAP for such varieties as IT93K-452-1, IT96K-113-6, IT93K-686-2, DANILA, IT97K-1034-14, IT97K-508-2, and IT96D-648. The highest nodulating cultivar is DANILA which produced consistently high nodules up to 28 DAP. Even at 35 DAP DANILA ranked among the varieties with highest number of nodules. For some others,nodulation increased significantly between 14DAP and 21DAP.This was noted for varieties IT93k-452-1,IT96k-113-6,IT93k-680-2,Danila,IT97k-103414,IT97k-508-2, and IT96D-648.The highest nodulation cultivar is Danila which produced consistently high nodules up to 28DAP.Even at 35 DAP,DANILA ranked among the varieties with highest no of nodules.

\section{Agronomic Traits Of Cowpea Lines}

Significant differences were observed among the varieties for number of days to attainment of $50 \%$ flowering, 90\% maturity, as well as pod yield and grain yield The varieties attained $50 \%$ flowering between 45 DAP and 50 DAP. The earliest to attain $50 \%$ flowering were IT93K-452-1, IT97K-837-8, IT97K-1034-94, IT97K-403-2 (45 DAP) while IT95K-1091-3 attained 50\% flowering at 50 DAP. Days to 90\% maturity varied from 69 DAP to 77 DAP for IT960-651 and Ife brown respectively. Consequently, grain filling periods for the varieties were close. This varied from 22 days for IT94K-437-1 and 29 days for Ife Brown as shown in Table 2. 
Table 2: Analysis of Variance on the Agronomic Traits of Cowpea Lines

\begin{tabular}{|l|l|l|l|}
\hline Varieties & Days to 50\% flowering & Days to 90\% maturity & Grain filling \\
\hline IT95K-366-1 & $47 \mathrm{de}$ & $71 \mathrm{ef}$ & $25 \mathrm{bc}$ \\
\hline IT93K-452-1 & $45 \mathrm{gh}$ & $71 \mathrm{ef}$ & $25 \mathrm{bc}$ \\
\hline IT95K-1090-12 & $48 \mathrm{~cd}$ & $72 \mathrm{dc}$ & $24 \mathrm{bc}$ \\
\hline IT96D-651 & $46 \mathrm{fg}$ & $69 \mathrm{~h}$ & $23 \mathrm{bc}$ \\
\hline IT96K-113-6 & $46 \mathrm{f}$ & $71 \mathrm{ef}$ & $25 \mathrm{bc}$ \\
\hline IT93-686-2 & $47 \mathrm{de}$ & $72 \mathrm{e}$ & $24 \mathrm{bc}$ \\
\hline IT97K-608-14 & $49 \mathrm{~b}$ & $73 \mathrm{~cd}$ & $23 \mathrm{bc}$ \\
\hline IT97K-837-8 & $45 \mathrm{gh}$ & $71 \mathrm{ef}$ & $25 \mathrm{bc}$ \\
\hline DANILA & $47 \mathrm{de}$ & $73 \mathrm{~cd}$ & $25 \mathrm{bc}$ \\
\hline IT97K-1034-94 & $45 \mathrm{~h}$ & $71 \mathrm{ef}$ & $27 \mathrm{ab}$ \\
\hline IT97K-508-2 & $49 \mathrm{~b}$ & $73 \mathrm{~cd}$ & $24 \mathrm{bc}$ \\
\hline IT95K-1091-3 & $50 \mathrm{a}$ & $74 \mathrm{~b}$ & $24 \mathrm{bc}$ \\
\hline 1T97K-499-8 & $46 \mathrm{fg}$ & $71 \mathrm{ef}$ & $25 \mathrm{bc}$ \\
\hline IT97K-819-180 & $49 \mathrm{~b}$ & $73 \mathrm{c}$ & $24 \mathrm{bc}$ \\
\hline IT94K-437-1 & $48 \mathrm{c}$ & $71 \mathrm{ef}$ & $22 \mathrm{c}$ \\
\hline IT97K-403-2 & $45 \mathrm{gh}$ & $72 \mathrm{de}$ & $27 \mathrm{ab}$ \\
\hline IT97-499-39 & $48 \mathrm{~cd}$ & $72 \mathrm{de}$ & $24 \mathrm{bc}$ \\
\hline IT960-648 & $46 \mathrm{fg}$ & $70 \mathrm{~g}$ & $24 \mathrm{bc}$ \\
\hline IT97K-497-2 & $47 \mathrm{de}$ & $71 \mathrm{ef}$ & $24 \mathrm{bc}$ \\
\hline IT86D-719 & $46 \mathrm{fg}$ & $70 \mathrm{~g}$ & $24 \mathrm{bc}$ \\
\hline IFE BROWN & $48 \mathrm{~cd}$ & $77 \mathrm{a}$ & $29 \mathrm{a}$ \\
\hline & & & \\
\hline SE & 0.65 & 0.75 & 0.89 \\
\hline
\end{tabular}

Means with same alphabets along the column are not statistically significantly different from one another according to Duncan's Multiple Range Test (DMRT) at 0.05 level of probability.

\section{Yield and yield components of cowpea lines}

Number of peduncle per plant varied between 9 for, IT96K-113-6 and 19 for IT97K-819-180. Ife brown recorded the highest number (3) of pods per peduncle and pods per plant, which varied between 24 for Ife brown and 8 for IT96K-113-6 and IT97K-499-8. Weight of 100 seeds from variety were significantly different from one another, IT93K-452 is significantly different in weight of 100 seeds $(22.063 \mathrm{~g})$ from other varieties like Ife brown, IT860-719, IT95K-1090-12 among others. Number of seeds/pod ranged between 7 for IT96K-113-6, IT960-648 and 12 for IT95K-1091-3. Length of pod varied between $(16.47 \mathrm{~cm})$ for IT97K1034_94 and $(11.02 \mathrm{~cm})$ for DANILLA. Cowpea fodder weight ranged between 1.733t for IT860-719 and 0.25t for IT97K-403-2. 15 varieties gave yield comparable to the Ife brown (local check while six others were not better than the check variety in terms of grain yield. Highest pod yield was recorded by Ife brown as compared to IT97K-499-8 that yield $1864 \mathrm{~kg} / \mathrm{ha}$ as shown in Table 3 .

TABLE 3: Analysis of Variance on yield and yield components of cowpea lines.

\begin{tabular}{|c|c|c|c|c|c|c|c|c|c|}
\hline Varieties & $\begin{array}{l}\text { Pod yield } \\
\mathrm{kg} / \mathrm{ha}\end{array}$ & $\begin{array}{l}\text { Total seed } \\
\text { yield } \mathrm{kg} / \mathrm{ha}\end{array}$ & $\begin{array}{l}\text { Cowpea } \\
\text { fodder t/ha }\end{array}$ & $\begin{array}{l}\text { Length of } \\
\text { pod (cm) }\end{array}$ & $\begin{array}{l}\text { Seed } \\
\text { pod }\end{array}$ & $\begin{array}{l}\text { Peduncles } \\
\text { plant }\end{array}$ & $\begin{array}{l}\text { Pod per } \\
\text { peduncle }\end{array}$ & $\begin{array}{l}\text { Pod/ } \\
\text { plant }\end{array}$ & $\begin{array}{l}100 \text { seed } \\
\text { weight }\end{array}$ \\
\hline IT95K-366-1 & $2745 b c$ & $1257 \mathrm{~b}$ & 1.143 & $13.97 \mathrm{de}$ & $10 \mathrm{f}$ & $13 \mathrm{f}$ & $2 \mathrm{~b}$ & $11 \mathrm{~g}$ & $12.420 \mathrm{k}$ \\
\hline IT93K-452-1 & $3129 \mathrm{bc}$ & $1975 \mathrm{ab}$ & 1.040 & $12.27 \mathrm{~h}$ & $8 g$ & $12 \mathrm{~g}$ & $2 b$ & $11 \mathrm{~g}$ & $22.063 \mathrm{a}$ \\
\hline IT96D-651 & $4268 \mathrm{abc}$ & $2475 \mathrm{ab}$ & 0.963 & $13.90 \mathrm{de}$ & $8 \mathrm{~h}$ & $11 \mathrm{~g}$ & $2 \mathrm{~b}$ & $14 \mathrm{c}$ & $16.870 \mathrm{~g}$ \\
\hline IT96K-113-6 & $5332 \mathrm{ab}$ & $2392 \mathrm{ab}$ & 0.777 & $13.17 \mathrm{fg}$ & $7 \mathrm{i}$ & $9 \mathrm{~h}$ & $2 \mathrm{~b}$ & $8 \mathrm{i}$ & $20.587 \mathrm{~b}$ \\
\hline IT97K-837-8 & $2831 \mathrm{bc}$ & $1644 \mathrm{ab}$ & 0.637 & $12.97 \mathrm{~g}$ & $8 \mathrm{~h}$ & $11 \mathrm{~g}$ & $2 \mathrm{~b}$ & 10gh & $19.633 c$ \\
\hline DANILA & $1913 c$ & $1105 \mathrm{~b}$ & 1.080 & $11.20 \mathrm{i}$ & $10 \mathrm{de}$ & $15 \mathrm{cde}$ & $2 \mathrm{~b}$ & $12 \mathrm{def}$ & $18.867 \mathrm{de}$ \\
\hline IT97K-1034-94 & $1865 \mathrm{c}$ & $1330 \mathrm{~b}$ & 1.247 & $16.47 \mathrm{a}$ & 8hi & $12 \mathrm{~g}$ & $2 b$ & $9 \mathrm{~h}$ & $16.670 \mathrm{~g}$ \\
\hline IT97K-508-2 & $2109 c$ & $1443 \mathrm{ab}$ & 1.060 & $16.13 \mathrm{a}$ & $10 \mathrm{~cd}$ & $15 \mathrm{~cd}$ & $2 \mathrm{~b}$ & $13 \mathrm{cde}$ & $19.107 \mathrm{~cd}$ \\
\hline IT95K-1091-3 & $3504 b c$ & $1702 \mathrm{ab}$ & 1.1110 & $14.40 \mathrm{~cd}$ & $12 a$ & $15 \mathrm{~cd}$ & $2 \mathrm{~b}$ & $16 \mathrm{~b}$ & $16.693 \mathrm{~g}$ \\
\hline IT97-499-39 & $4181 \mathrm{abc}$ & $2301 \mathrm{ab}$ & 0.980 & $14.77 \mathrm{c}$ & $10 \mathrm{~cd}$ & $13 \mathrm{f}$ & $2 \mathrm{~b}$ & $14 \mathrm{c}$ & $17.937 \mathrm{f}$ \\
\hline IT960-648 & $4262 \mathrm{abc}$ & $2397 \mathrm{ab}$ & 0.643 & $14.63 \mathrm{~cd}$ & $7 \mathrm{j}$ & $15 \mathrm{bc}$ & $2 \mathrm{~b}$ & $13 \mathrm{~cd}$ & $18.860 \mathrm{de}$ \\
\hline IT97K-497-2 & $4057 \mathrm{abc}$ & $1912 \mathrm{ab}$ & 0.927 & $15.33 \mathrm{~b}$ & $10 \mathrm{c}$ & $14 \mathrm{ef}$ & $2 \mathrm{~b}$ & $15 \mathrm{bc}$ & $17.283 \mathrm{~g}$ \\
\hline IT86D-719 & $2988 \mathrm{bc}$ & $1697 \mathrm{ab}$ & 1.733 & $11.87 \mathrm{~b}$ & $9 \mathrm{fg}$ & $12 \mathrm{~g}$ & $2 \mathrm{~b}$ & $9 \mathrm{~h}$ & $15.330 \mathrm{i}$ \\
\hline IFE BROWN & $6550 \mathrm{a}$ & $2991 \mathrm{a}$ & 0.677 & $12.03 \mathrm{~h}$ & $11 \mathrm{c}$ & $16 \mathrm{~b}$ & $3 a$ & $24 a$ & $14.713 \mathrm{j}$ \\
\hline SE $\underline{ }$ & 47322728 & 146338.05 & 0.07 & 0.48 & 0.41 & 2.44 & 0.01 & 2.67 & 0.58 \\
\hline
\end{tabular}


The variance attained $50 \%$ flowering between 45 Dap and 50 DAP. The earliest to attain $50 \%$ flowering were IT93K-452-1, IT97K-837-8, IT97K-1034-94, IT97K-403-2 (45 DAP) while IT95K-1091-3 attained 50\% flowering at 50 DAP. Days to 90\% maturity varied from 69 DAP to 77 DAP for IT960-651 and Ife brown respectively. Consequently grain filling periods for the varieties were close. This varied from 22 days for T94K-437-1 and 29 days for Ife brown as shown in table 2. Number of peduncle per plant varied between 9 for IT96K-113-6 and 19 for IT97K-819-180. Ife brown recorded the highest number (3) of pods per peduncle and pods per plant, which varied between 24 for Ife brown and 8 for IT96K-113-6 and IT97K499-8. Weight of 100 seeds from varieties were significantly different from one another, IT93K-452 is significantly different in weight of 100 seeds $(22.063 \mathrm{~g}$ ) from other varieties like Ife brown, IT860-719, IT95k-1090-12 among others. Number of seeds/pod ranged between 7 for IT96K-113-6, IT96D-648 and 12 for IT95K-1091-3. Length of pod varied between $(16.47 \mathrm{~cm})$ for IT97K-1034-94 and $(11.20 \mathrm{~cm})$ for DANILA.Cowpea fodder weight ranged between 1.733t for IT860-719 and 0.25t for IT97K-403-2. 15 varieties gave yield comparable to the Ife Brown (local check while six others were not better than the check variety in terms of grain yield).Highest pod yield was also recorded by Ife Brown as compared to IT97K-499-8 that yield $1864 \mathrm{~kg} / \mathrm{ha}$ as shown in table 3 .

\section{Relationship Among Various Agronomic Traits In Cowpea}

Cowpea seed yield was positively correlated with number and weight of nodules; total dry matter production; number of pods per plant; pods per peduncle, number of days to $50 \%$ flowering and $90 \%$ maturity as well as pod yield as shown in table 4 .

Table 4: Correlation coefficient showing relation among various agronomic traits in cowpea.

\begin{tabular}{|c|c|c|c|c|c|c|c|c|c|c|c|}
\hline & $\begin{array}{l}100 S \\
W\end{array}$ & $\begin{array}{l}\text { NOD } \\
N O .\end{array}$ & $N D W$ & $T D M$ & $\begin{array}{l}\text { PED/ } \\
P T\end{array}$ & $\begin{array}{l}P O D / \\
P T\end{array}$ & $\begin{array}{l}P O D \\
P E D\end{array}$ & $50 \% F$ & $90 \% M$ & $P Y$ & $S Y$ \\
\hline $100 S W$ & 1.00 & & & & & & & & & & \\
\hline $\begin{array}{l}\text { NOD } \\
N O .\end{array}$ & 0.14 & 1.00 & & & & & & & & & \\
\hline$N D W$ & 0.04 & $0.80 *$ & 1.00 & & & & & & & & \\
\hline$T D M$ & 0.09 & $0.61 *$ & $0.71 *$ & 1.00 & & & & & & & \\
\hline$P E D / P T$ & 0.20 & $0.41 *$ & $0.41 *$ & $0.38 *$ & 1.00 & & & & & & \\
\hline$P O D / P T$ & 0.02 & $0.32 *$ & $0.37 *$ & $0.39 *$ & $0.28 *$ & 1.00 & & & & & \\
\hline $\begin{array}{l}P O D \\
P E D\end{array}$ & -0.25 & $0.30 *$ & $0.39 *$ & $0.38 *$ & $0.27 *$ & $0.28 *$ & 1.00 & & & & \\
\hline $50 \% \mathrm{~F}$ & 0.01 & 0.20 & $0.39 *$ & $0.32 *$ & $0.40 *$ & $0.41 *$ & 0.05 & 1.00 & & & \\
\hline $90 \% M$ & 0.01 & $0.37 *$ & $0.45^{*}$ & $0.56^{*}$ & $0.51 *$ & $0.54 *$ & 0.16 & $0.72 *$ & 1.00 & & \\
\hline$P Y$ & 0.04 & 0.20 & $0.28 *$ & $0.35 *$ & 0.15 & $0.36 *$ & $0.34 *$ & $0.36^{*}$ & $0.14-*$ & 1.00 & \\
\hline$S Y$ & 0.14 & $0.27 *$ & $0.29 *$ & $0.37 *$ & 0.15 & $0.30 *$ & $0.34 *$ & $0.36^{*}$ & $0.36^{*}$ & $0.88^{*}$ & 1.00 \\
\hline
\end{tabular}

Key:

$\begin{array}{ll}\text { 1OOSW- } & \text { One hundred seed weight } \\ \text { NOD NO- } & \text { Nodule number } \\ \text { NDW - } & \text { Nodule Dry Weight } \\ \text { TDM - } & \text { Total Dry Weight } \\ \text { PED/PT- } & \text { Peduncle per plant } \\ \text { POD/PT- } & \text { Pod per plant }\end{array}$

$\begin{array}{lll}\text { POD/PED } & - & \text { Pod per peduncle } \\ 50 \% \mathrm{~F} & - & \text { Days to } 50 \% \text { flowering } \\ 90 \% \mathrm{M} & - & \text { Days to } 90 \% \text { maturity } \\ \text { PY } & - & \text { Pod yield } \\ \text { SY } & - & \text { Seed yield }\end{array}$

Cowpea seed yield was positively correlated with number and weight of nodules; total dry matter production; number of pods per plant; pods per peduncle; number of days to $50 \%$ flowering and $90 \%$ maturity as well as pod yield (table 4).Regression analysis which was done with total nodulation against time and total dry matter against time had a linear relationship. While the number of nodules slightly decreased with age of plant, the dry weight of nodules and dry matter accumulation increased with the age of plants. (Figure 1, 2 and 3 respectively). 
- Total nodule number- Linear (total nodule number)

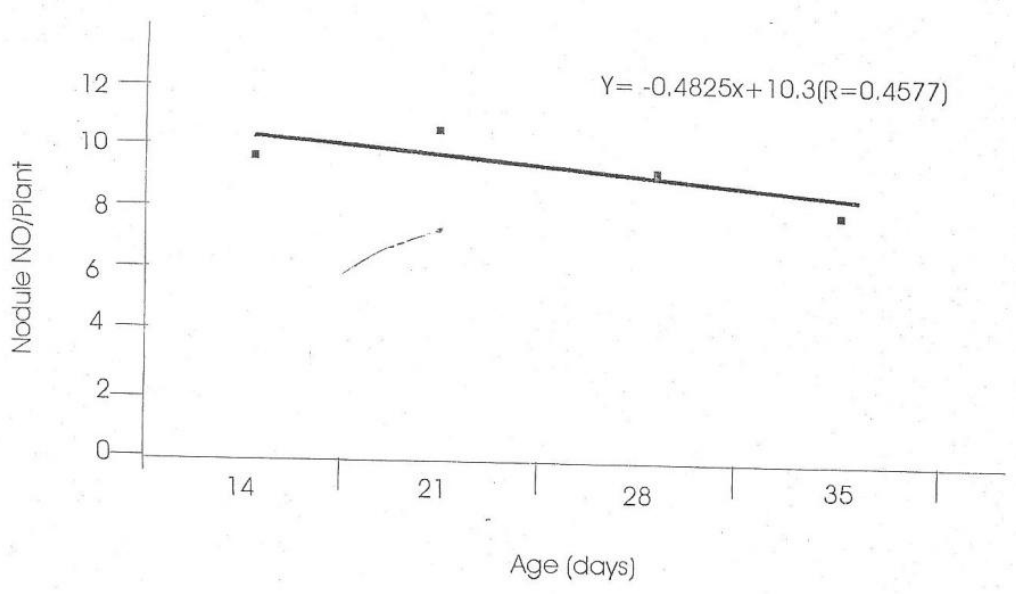

Figure 1: Regression Analysis of Total Nodule against Time

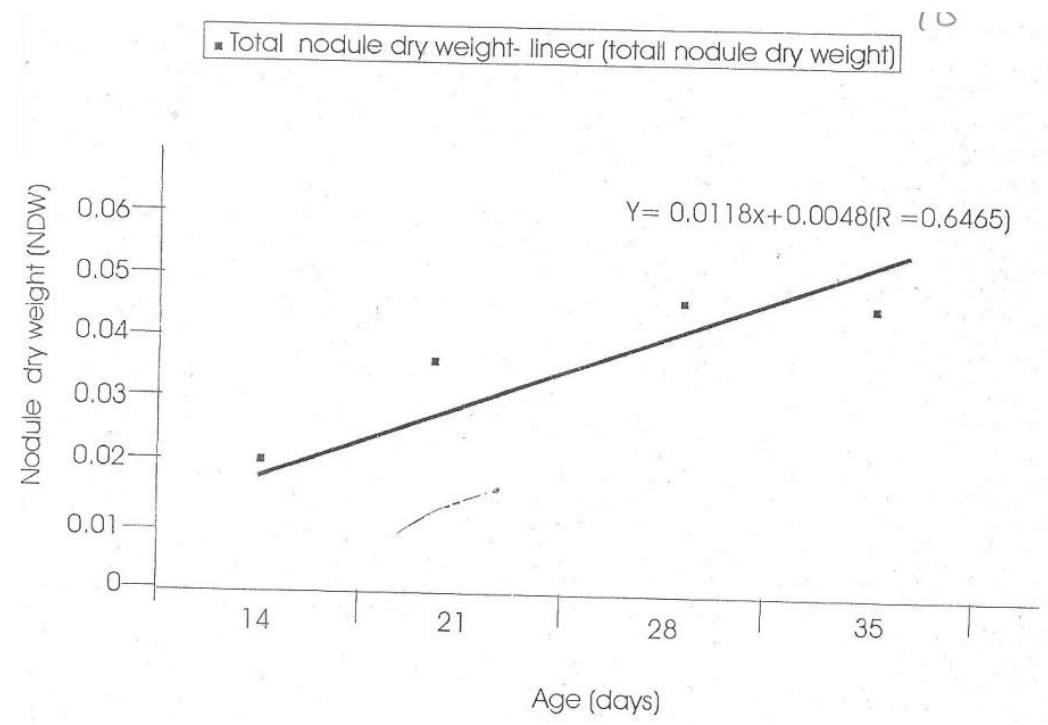

Figure II: Regression Analysis of Nodule Dry Weight Against Time.

- Total dry matter- linear (totall dry matter)

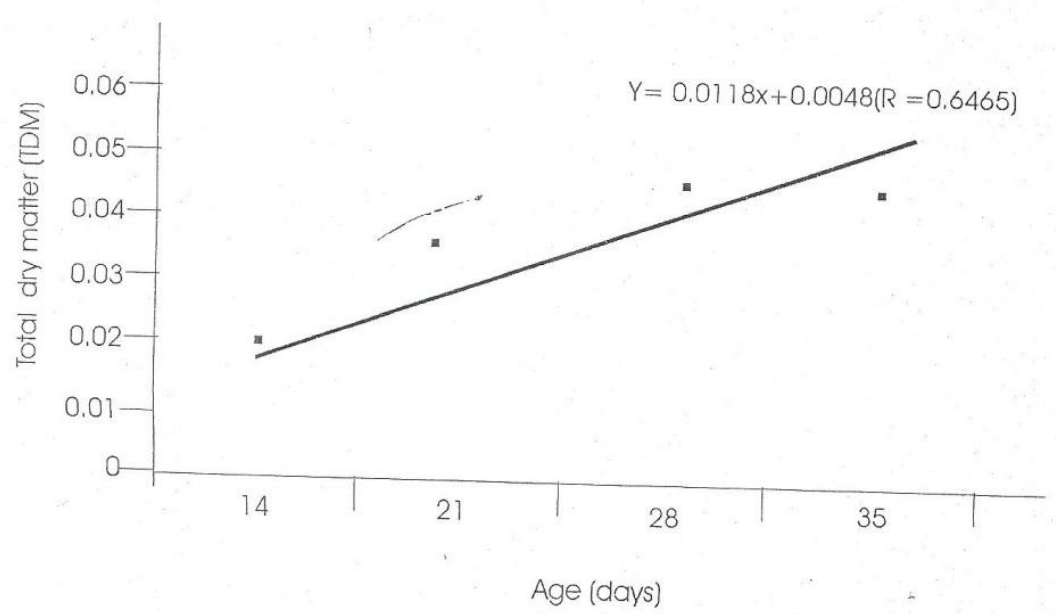

Figure III: Regression Analysis of Total Dry Matter Accumulation against Time 


\section{Discussion}

One of the economic importance of legumes is the ability to utilize atmospheric nitrogen through the nitrogen fixing ability of the rhizobium in the root. Generally, when rhizobia traps atmospheric nitrogen and convert it to nitrate, it becomes useful for vegetative growth of the crop. The cowpea varieties studied exhibited varying amount of nodulation. DANILA was the highest nodulation variety with 81 nodules per plant while, IT97K-819-180 was the least nodulating varieties with 21 nodules per plant. The increase in nodule weight with time observe for the varieties suggest that while number of nodules may decrease with time, nitrogen fixation and accumulation of fixed nitrate may increase and this could be reflected in higher nodule weight as observed in this study.Attainment of 50\% flowering by the varieties were very similar hence they attained $50 \%$ flowering at about the same time between 47-49 DAP. Hence there is synchronous flowering of cultivars in this study. This is reflected in grain filling period and attain of maturity. On the average, varieties that flowered early had a short maturity period, IT96D-651 flowered at 46DAP and matured 69DAP while the varieties that flowered late had a long maturity period. This observation is similar to that for variety Ife brown which flowered at 48DAP and matured 77DAP. IT95k-1091-3 flowered at 50 DAP and matured at 74 DAP. Varieties that flowered early had a long grain filling period. Varieties such as IT97k-1034-94, IT97k-403-2, IT93k-452-1, IT97k-837-8 flowered at 45 DAP and had a long grain filling period of 27 DAP. The result confirm earlier finding of Wein and Ackah (1988), Alofe and Amusan (1992) who observed that cowpea varietythat flowered early will have a longer grain filling period. Generally, the maturity period of cultivars were similar. This is advantageous in that harvesting operation can be done once or twice thereby reducing labour and time. The differences in earliness to flowing were not reflected in the number of pods per plant produced. This is in agreement with the observation of Alofe and Amusan (1980).This study showed significant differences among the varieties evaluated as in length pod, seeds per pod and peduncles per plant. This indicates significant varietal difference among the varieties. Similar observations were noted by Singh and Mehndirrate (1989). Among the varieties studied, Ife brown had the highest number of pods/plant, likewise the highest grain yield. This confirms the report of Afolabi (1990) that the most important variable to seed yield is the numbers of pods per plant.

Correlation coefficient among the agronomic traits and yield components showed that seed yield has a significant positive correlation with pods per plant, pod per peduncle, days to $50 \%$ flowering, days to $90 \%$ percent maturity. This suggest that grain yield could be improved by selecting for these characters. This agree with a similar observation made by Okeleyeet al (1999). The relationship between peduncle per plant and pods per plant is also worthy of note. Plants with many peduncles tended to bear more pods and consequently higher seed yield. This implies that an increase or decrease in the values of these traits will cause corresponding change in yield of the varieties. This result confirms the result of Veenupshappaet al (1990) which showed significant correlation between pods per plant and yield. There was no significant correlation between 100 seed weight and yield. This agrees with the report of Leleji (1981) and Aolabi (1980). This result suggest that out of the three yield components measured, two (pod per plant and pod per peduncle) had a significant positive correlation with yield. Nodulation had a significant positive correlation with yield. This implies that the role of nodules is the supply of nutrients to the cowpea plant has an enormous contribution to seed yield. During nodulation, $\mathrm{NO}_{3}$ (nitrate) is produced from the symbiotic association between rhizobium and the plant root. The $\mathrm{NO}_{3}-\mathrm{N}$-fixed are utilized by the plant for their vegetative growth and yield. About 15 of the varieties compared favorably with the local check (Ife brown) for grain yield. Although the grain yield of DANILA is significantly lower than most of the improved varieties evaluated, its nodulation is the highest.The implication of these result is that the varieties can be growth for different purposes like highly nodulating and dual purpose varieties. Highly nodulation varieties are expected to contribute to soil nitrogen. So varieties. Like DANILA, Ife brown, IT96k-113-6 that were the best three in nodulation would be useful for improving soil nitrogen particularly under intensive land use when the biomass is removed. For fodder production, varieties with high biomass yield would be suitable. Such can be used in crop/livestock integrated system. DANILA with about $1.080 \mathrm{t} / \mathrm{ha}$ biomass yield compared with seven others. These were also good in terms of grain yield producing above one tonne per hectare. These varieties IT95k-366-1, IT93k-452-1 IT95k-1090-12, IT97k-1034-94, IT97k-508-2, IT95k-1091-3, and IT86D719 are recommended as dual purpose varieties, however, since this study is just one year, it might need to be repeated.

\section{Conclusion And Recommendation}

This study showed that nodule number and nodule dry weight are both positively correlated with biomass production and grain yield. The varieties that were observed to have high nodule production are recommended for intensive cropping system. Other varieties with high biomass and grain yield are classified as dual purpose varieties and can be used for integrated livestock cropping system.

The synchronous flowering and maturity date of these varieties may be an advantage to farmers in that harvest operations can be done once. This has implication for time and labour utilization to the farmers. 


\section{References}

[1]. Aghali A. M. (1991): Studies on Cowpea Farming Practices in Nigeria with Emphasis on Insect Pest Control. Tropical Pest management 37: $71-74$

[2]. Afolabi G. D. (1990): Growth and Development of Three Varieties of Cowpea in Western Nigeria Yield and Dry Matter Production. Tropical Grain Legume Bulletin No. 26; $18-20$

[3]. Alofe, C. O. and Amusan A. A. (1992): Partitioning Dry matter in relation to Yield Performance in Five Cultivars of Cowpea (VignaUnguiculata(L) Walp). Ife Journal of Agric Vol. 4; $182-198$.

[4]. Miller J. C., K. W. Zary and G. C. Fernandes (1986).Inheritance of $N_{2}$ Fixation efficiency in Cowpea.Euphytica 35: 551 - 560.

[5]. Okeleye A. I., O. J. Ariyo and V. I. Olowe (1999).Evaluation of Early and Medium Duration Cowpea (V. Unguiculata(L) Walp) Cultivar for gronomic Traits and Grain Yield.The Nigerian Agricultural Journal.30: 1 - 11 .

[6]. Leleji O. I. (1998). The Extent of Hybrid Vigour for Yield and Yield Components in Cowpea.(V. Unguiculata(L) Walp) in Savanna Region of Nigeria.Nigeria J. Agric. Sci. 32: 5 - 16.

[7]. Singh B. B. (1993). Cowpea (V. Unguiculata) Breeding: Archival Report (1988 - 92)

[8]. Singh B. B., D. R. Mohan, K. E. Dashiell, and L.E.N. Jackal (1997).Advances in Cowpea Research.Co-publication of International Institute of Tropical Agriculture (IITA) and Japan International Research Center for Agricultural Science (JIRCAS) IITA, Ibadan, Nigeria.Sayce Publication Deven, U.K.: 32 - 33.

[9]. Singh E. L. and P.O. Mehndiratta (1989).Genetic Variability and Correlation Studies on Cowpea.Indian Journal Plant Breeding 29: $104-109$.

[10]. Veenupshappa, K., S. R. Hiramach, and G. Shivashankar (1990). Note on Correlation in Different Segregation Generations of Cowpea. Indian Journal of Agricultural Science.

[11]. Wein H. C. and E. E. Ackah (1988). Pod Development Period in Cowpea. Varietal Differences as Related to seed Characters and Environmental Effects. Crop Science 18: $771-774$. 